\title{
Democracy in an Age of Pandemic: Civil and Human Rights and the Choice between Freedom and Safety
}

\author{
Pero Maldini \\ University of Dubrovnik, Department of Mass Communication, Croatia \\ e-mail:pero.maldini@unidu.hr
}

\begin{abstract}
The health and economic crisis caused by the COVID-19 pandemic has grown into a political crisis. It manifests itself primarily in challenges to the institutions of liberal democracy, particularly in ensuring a legitimate legal and political framework for action and crisis management in an emergency situation. This paper examines the implementation of public health measures to protect life and health (epidemiological measures, vaccinations), which by their very nature involve restrictions on civil liberties, and analyzes their legitimacy and appropriateness against the standards of liberal democracy. The theoretical and legal-political framework of the analysis is the relationship between freedom and safety, i.e. between the civil rights and liberties guaranteed in liberal democracy and the right to life and health as a fundamental human right. Based on the distinction between these two concepts and the analysis of the scope and manner of the implementation of public health measures - especially in the current context of the crisis of liberal democracy and the populist instrumentalization of civil rights for certain political goals and the state of infodemics - the specifics of this relationship are determined. Following the findings of this analysis, it is concluded that civil rights and human rights are not mutually exclusive, despite the competitive relationship and tension between individual liberty and public security - which is particularly emphasized in a pandemic situation. On the contrary, they complement each other and are prerequisites for each other. This path points to the possibilities of achieving a balance between them, and thus to the possibilities of overcoming the crisis caused by the pandemic.
\end{abstract}

Key words: civil rights, human rights, epidemiological measures, vaccination, COVID-19 pandemic. 
Those who would give up essential liberty to purchase a little temporary safety, deserve neither liberty nor safety. Benjamin Franklin

It is health that is real wealth and not pieces of gold and silver.

Mahatma Gandhi

\section{Introduction}

The outbreak of the COVID-19 epidemic has created not only a health crisis but also a political crisis, reflected in the challenges for political authorities to effectively manage the crisis while preserving the democratic process and protecting civil rights. At the same time, at stake are the institutions of liberal democracy and the adequacy of the constitutional and legal order, which provide a legitimate political and legal framework for governing and acting under conditions of emergency and general danger.

In this context, in many societies, the content and scope of public health measures and their acceptability from the point of view of the protection of liberties and civil rights are at the heart of most political conflicts. This is particularly pronounced in democratic societies with deeply rooted liberal values and heightened distrust of government and state action, especially when such action is perceived as an attempt by government to encroach on civil rights and liberties. The examples of many countries where political authorities have used the pandemic situation to strengthen their control over society are an additional warning. On the other hand, there is the need to protect the lives and health of citizens as an obligation and responsibility of the government and the state. Crisis management and protection of public health is their primary task, thus legitimizing the establishment and implementation of epidemiological measures. This in turn raises quite specific questions, namely: to what extent may the state legitimately restrict the freedoms of its citizens in order to serve the common good? Moreover, should the state restrict an individual's choice in order to prevent him from harming himself, especially when such a choice becomes the harm of another? To what extent is the protection of health necessary as a public interest, and to what extent is it an excuse for government to strengthen its position and/or reduce civil liberties?

These questions imply two concepts: the right of the individual and the right of the community. While the former encompasses freedom, equality and political rights - as fundamental values and principles of democracy, the latter encompasses public health measures - as the right and duty of the state to protect health as a public good and general interest. In a political-legal sense, this can be expressed as the relationship between individual freedom as a civil right guaranteed by a democratic order and health 
protection as a value derived from a fundamental human right - the right to life which a democratic state must ensure. It is this tension between individual liberty and public safety that is the central problem of the political crisis that the COVID-19 pandemic has spawned. This article therefore seeks to analyze the key features of this relationship and its evolution in the social and political context of democracy, and point to the possibilities of striking a balance between individual freedom and public safety.

\section{Political and legal framework}

Consequently, the theoretical framework for the analysis of this relationship presupposes two basic political and legal concepts, namely the concept of human rights and the concept of civil rights. Although there is no consensus on the definition and scope of human and civil rights, it can be argued, on the basis of the fundamental documents that regulate them, that human rights include fundamental and universal rights, such as the right to life, the right to liberty and security, the right to a fair trial, respect for private and family life, the prohibition of torture, slavery, forced labor and discrimination. Civil rights are the achievement of democratic development from the social revolutions to the present day and include political rights, social, economic and cultural rights, and group rights or solidarity. Civil rights are based on individual and political freedom (freedom of expression, assembly, movement, political organization, conscience and religion), equality and the rule of law, and popular sovereignty. A democratic state and government guarantee these rights for every citizen. However, freedom is not unlimited. It is limited by the freedom of others, about which there is a consensus expressed in the Constitution and laws. This limitation is built into the foundations of the constitution of a democratic polity, so that the use of the rights of each person is limited when other members of society are prevented from enjoying the same rights. Law is an expression of the general will, it seeks to promote equality of rights and the prohibition of all acts harmful to society. This is precisely the basis for the legitimate action of the state in a situation where it is necessary to temporarily restrict part of the civil rights in order to protect the human, especially the basic -right to life and health. ${ }^{1}$

This means that citizens, in the exercise of their rights and freedoms, may be subjected only to such restrictions as are prescribed by law to secure the necessary recognition of and respect for the rights and freedoms of others and to meet the just requirements of morality, public order, and the general welfare in a democratic society. It should be noted that the possibility of any restriction must be provided for in advance by the

1 This is explicitly stated in Articles 2 and 4 of the Declaration of the Rights of Man and of the Citizen of 1789, Articles 3 and 29 of the UN Universal Declaration of Human Rights of 1949, and Article 5 (1) (e) and Articles 15 and 18. The European Convention on Human Rights of 1950 and Article 4 of the International Covenant on Civil and Political Rights of 1966. 
Constitution or a law, that the restriction must be proportionate to the need, that it may not be applied to fundamental human rights (right to life, prohibition of torture, punishment and degrading treatment), and that a restriction may be introduced only for the protection of the rights and freedoms of others. For example, the introduction of quarantine to prevent the spread of contagious diseases, the closure of borders, the prohibition of public gatherings or the introduction of curfews to maintain public safety (in situations of war or natural disasters) restrict the freedom of movement, assembly, work, education and/or practice of religion. The introduction of security supervision in a situation where the democratic constitutional order is threatened restricts individual and political liberties and privacy. However, all these restrictions may be introduced temporarily as long as the need for them exists. Furthermore, regardless of the circumstances, these restrictions must not violate the equality of citizens in such a way that they are discriminated against in terms of gender, age, language, ethnic, cultural, religious, racial and/or socio-economic affiliation. Finally, extraordinary measures that restrict civil rights must be publicly announced and adequately communicated, and the restrictions must be clearly defined and prescribed by law. Then the use of such measures is legitimate.

A central principle of public health - which has its basis in the protection of the life and health of citizens - is the requirement that those who are ill or infected undergo treatment and/or isolation to prevent the spread of disease to others. The use of such measures always raises the question whether the threat to health and the severity and transmission of the disease justify the deprivation of liberty. This question cannot be answered without facing the tension between the interests of the individual and the interests of the collective, that is, between liberty and safety. The privileging of one of the two principles inevitably leads to the violation of the other, i.e. to an imbalance that implicitly calls into question the fundamental democratic principles - freedom, equality and civil rights.

\section{Public health between the protection of the public interest and the rights of the individual} much older than modern liberal democracy and dates back to times when the concepts of human and civil rights were not yet known. However, even then, despite the social and political inequality of societies at the time, tensions between the need to apply public health measures and their acceptability in relation to the consequences were evident. After all, it was the measures to combat epidemics, which claimed many lives over the centuries that were the first public health measures, inherently involving restrictions.

Thus, the first quarantine was invented in the Republic of Dubrovnik in 1377, as a physically separate and organized space (lazaretto) and a set of regulations that gov- 
erned the entry of people and goods into the city and their strict surveillance to protect against contagion. Even then, the problem of the application of public health regulations arose, which manifested itself not only in the slowing down of economic activity, but also in the possibility of their abuse (especially in the treatment of political opponents and the possibility of their removal). Therefore, the authorities were aware of this danger from the very beginning and prevented its abuse by law. Given that the epidemics of the time (plague, cholera, and other contagious diseases) devastated entire societies demographically and economically, an awareness quickly developed of the benefits of epidemiological measures in relation to the harm that contagion brought to the entire community. Many other European cities and countries later adopted the quarantine system thus established (Baldwin, 1999: 559; Borovečki \& Lang, 2001, 304-305). Although the specific mechanisms of the disease were still poorly understood, the collective approach to infectious diseases proved successful.

Conflicts over the scope of public health and the acceptability of its measures occurred more frequently in the fight against infectious diseases in the $19^{\text {th }}$ and early $20^{\text {th }}$ centuries and have continued to varying degrees today. Scientific advances in the $19^{\text {th }}$ century, particularly the development of microbiology (the discoveries of L. Pasteur and R. Koch), greatly improved the understanding of how infections spread and thus epidemiology (Ackerknect, 1948; Baldwin, 1999: 195). This is the beginning of the modern conception of antiepidemic measures, which at the same time as they are used, gain opponents. These then turn against these measures mainly because of the economic consequences resulting from the restriction of the movement of goods and people, rather than because of the restriction of civil rights, which were still being developed at the time. However, it has been shown that poor housing and hygiene conditions and habits - as the main source of infection, especially in the slums - pose a threat not only to this population, but to society as a whole. Therefore, the protection of citizens from health hazards becomes a public responsibility and the implementation of these measures is taken over by the state.

It is in this context that the modern concept of public health develops, established from the beginning as an organized activity of the state in environmental sanitation, the prevention of contagions in the community, the education of individuals in the principles of personal hygiene, the organization of medical services for early detection and preventive treatment, and the development of social mechanisms for the protection and preservation of individual and community health. Two features of public health should be noted: First, it is concerned with the preventive rather than the curative aspect of health care, and second, it is concerned with health problems at the community level rather than at the individual level. Therefore, the focus of public health interventions is on prevention rather than treatment of disease, which is achieved through public health measures that include restrictions where necessary (Winslow, 1920). 
The rapid development of science and the inventions of the medical profession in the late 19 th and especially in the $20^{\text {th }}$ centuries created the basis for such treatment. The eradication of contagious and fatal diseases (tuberculosis, polio, typhoid, smallpox, measles, mumps, rubella, diphtheria, tetanus, pertussis, etc.) and the development of public health facilities established new health standards (Štampar, 1934). At the same time, the socioeconomic conditions of industrial society and rapidly growing cities, as well as the development of the middle class, influenced the preference for public health measures as a factor in improving the quality of life. The effects of these measures have been clearly visible through better health care and increased life expectancy. Given the benefits of public health to large groups in society, the state and government usually have a majority support in implementing public health measures.

This support is expressed passively, i.e., through the absence of major protests and compliance with government actions, especially in times of public health crises and the immediate threat of disease outbreak and spread, when the government has an immediate reason and justification for restrictions and coercion (e.g., quarantine, vaccination). At times when there is no such threat, resistance is expressed through political struggle and public protest, especially when laws are passed that regulate the area. At the same time, public reactions to the implementation of public health measures are much more pronounced in the US than in European democracies. This in turn stems from differences in democratic traditions, with more emphasis on individual freedoms in the US and more on equality in Europe. Thence also stems the entrenched suspicion toward the state and government in American democracy, in contrast to most European democracies where there is a clear tendency to rely on the state (especially the functions of the welfare state) and public policies that ensure equality and safety for citizens.

Although much more frequent than in Europe, protests by some citizen groups in the US against mandatory vaccination and government intrusion into privacy did not find much support, nor did they stop the government from implementing public health measures. The courts regularly ruled in favor of the government, not the plaintiffs, when deciding civil rights lawsuits. ${ }^{2}$

2 Of particular importance is the 1905 U.S. Supreme Court decision in Jacobson v. Massachusetts case, when the court upheld the states' powers to enforce compulsory vaccination laws, including police powers to combat the epidemic. The court's decision has been the basis for many subsequent rulings in similar cases. This, in turn, has defined nearly a century of practice in settling the conflict between the rights of the individual and the demands of the collective in matters of public health. The laws that followed included not only vaccination disputing but also controversial health and medical issues ranging from fluoridation of municipal water supplies, through abortion and euthanasia to the use of motorcycle helmets and the discouragement of the use of tobacco, alcohol, and fatty and sugary foods through high taxes (U.S. Reports: Jacobson v. Massachusetts, 197 U.S. 11, 1905; Colgrove \& Bayer, 2005; Gostin, 2017). 
The political and ethical implications of these judgments are extremely important, for they legally articulated the political view that individual liberty must be subordinated to the common good in certain situations. This means that the liberty guaranteed by the constitution of a democratic state to each of its citizens does not imply the absolute right of a citizen to be free from restraint at all times. Civil right also implies a civil obligation, particularly in relation to the common good, i.e. the public interest, which implies restrictions when it comes to protecting the public interest. The implementation of public health measures has thus stimulated a debate on the fundamental democratic principle of the relationship between rights and liberties and the relationship between the individual and the community. Referring to the laws passed by parliament - which represent the will of the people - the courts legitimize the right of the government to impose the restrictions contained in public health measures in order to protect the public interest, in particular the health of all citizens.

The legislation and jurisprudence of this period reflects the legacy of the $19^{\text {th }}$ century, when many laws were enacted that restricted individual liberties in order to promote an orderly society. This is understandable when we consider the socioeconomic and public health context of the period, which was characterized by the efforts of newly established municipal and government services to improve health and sanitary living conditions in the increasingly densely populated urban centers created by intensive industrial development. To achieve their goals, these services had to have broad powers to enforce measures to control disease and curb the spread of infection, including isolation and quarantine and compulsory vaccination.

\section{Vaccination as a litmus for the relationship between the rights of the individual and the rights of the state}

Campaigns against compulsory vaccination - as the most prominent preventive public health measure in the second half of the $19^{\text {th }}$ century - are less concerned with the medical or economic aspects of the measures than with the political ones. Opposition to compulsory vaccination has pronounced class connotations, so that anti-vaccination protests are actually protests against class inequality. This is because the laws that impose fines on vaccination refusers primarily affect the lower socioeconomic classes, placing them in an unequal position to others. The British government, for example, has had such a law since 1840 . It introduced a requirement to vaccinate infants against smallpox for the first three months. Later, in 1867, the law was extended to make vaccination compulsory for all children under 14 . Parents could be fined if they did not comply and imprisoned if they could not pay the fines. From 1871, fines were also extended to officials of local institutions if they failed to collect the fines. Such or similar practices were the cause of many public protests against vaccination and even violence in the following decades. Even then, scientists (e.g., A. R. Wallace, a prominent British biologist) stepped forward to warn of the ineffectiveness and health 
hazards of vaccination (Wolfe $\&$ Sharp, 2002). Admittedly, there were reasons for this at the time, as the first vaccines (against smallpox) actually had severe and frequent side effects due to the technological imperfections of the vaccine and general sanitary conditions (contamination by bacteria and other pathogens).

Anti-vaccination protests also occur in some other European countries (Sweden, France), but the epidemic of 1874 silences the protests and the majority of the population accepts the government measures. In the US, however, under pressure from anti-vaccinationists, compulsory vaccination laws are repealed in some states (California, Illinois, Indiana, Minnesota, Utah, West Virginia, Wisconsin), acknowledging religious and personal beliefs but accepting responsibility for the consequences. This also happened in Britain in 1898 in the form of allowing parents to refuse compulsory vaccination of their children if they signed a statement that they understood all the risks of such a decision. It also became the basis for later decisions in most other US states.

Despite protests, the serious and imminent threat of infectious disease in the late $19^{\text {th }}$ century was sufficient justification for the government to implement public health measures. With the eradication of the most serious infectious diseases in the first half of the $20^{\text {th }}$ century, however, public health gradually lost that character of urgency that would continue to justify the imposition of restrictions, and support for public health measures, especially those involving coercion or restraint, was relatively weak. Thus, as early as the beginning of the $20^{\text {th }}$ century, health education gradually supplanted coercion as the central approach to maintaining public health. Public health reforms include institutionalization as well as health education programs for broad social groups and methods of education and persuasion rather than coercion (Colgrove \& Bayer, 2005; Štampar, 1934). Authorities campaign and urge citizens to comply with prescribed measures, especially hygiene and sanitation ones. However, non-compliance with professional sanitary and epidemiological recommendations is characterized as immoral or criminal behavior and thus sanctioned. In this way, public pressure is used to try to influence compliance with the measures and public condemnation of violations.

In the period from the 1930s to the 1970s, the role of the state in health care was extremely strong and its powers relatively broad. The state has a major role in the provision and planning of health services, in health promotion and health education, and in the financing of health services. Public health interventions during this period include, most notably, infectious disease prevention programs through compulsory vaccination to immunize as many citizens as possible. Extensive vaccination has significantly reduced the number of infectious diseases, and some have even been nearly eradicated. As a result, chronic and malignant diseases are increasingly becoming a public health focus. Nevertheless, some restrictions remain, particularly with regard 
to compulsory vaccination (e.g. vaccination against polio, tuberculosis and measles as a prerequisite for children to start school). This, in turn, has generated much controversy - some of which continues to this day - leading to increasing conviction and explanation of the benefits of vaccination and decreasing compulsion.

\section{Post-democracy and the crisis of trust}

The structural changes brought about by technological and scientific development at the end of the last century have also altered the priorities of the public health system, which has faced the problem of growing public expenditure during this period. The crisis of the welfare state has also manifested itself in the high cost of health care, which has led to fiscal constraints and cuts in health and social programs and services since the end of the last century. At the same time, new health problems are emerging, such as AIDS, which are reaching epidemic proportions, problems caused by exposure to hazardous substances in industrial production, environmental pollution, and an increase in drug abuse and alcoholism. In this context, opponents of vaccination focus on problematizing the side effects of certain vaccines. Some pseudoscientific interpretations have contributed significantly to the growth of fear and distrust. ${ }^{3}$ Under conditions of already long absence of infectious disease hazards - especially in the most developed countries - citizens are more inclined to believe that the risk of vaccination (especially in children) is greater than the risk of infection, which increases the refusal rate of vaccination (Larson, 2016).

At the same time, public health's methods of combating AIDS (especially mandatory registration in public registries and mandatory HIV testing) have provoked widespread protests from many gay rights activists and civil liberties advocates. This wave of protest challenged long-standing assumptions that protected public health from constitutional scrutiny. Ultimately, this conflict led to the articulation of a new relationship between public health and individual privacy, that is, it led to public health policies that reconcile these two principles as much as possible (Bayer, 1989).

Security policies, fueled by terrorist attacks earlier this century, have expanded the government's powers to control citizens, which has further increased resistance from

3 A 1998 article by A. Wakefield in The Lancet exemplifies the implications for increasing vaccination refusal and declining vaccination rates. Without solid evidence (and with altered patient data), he claimed there was a link between vaccination against measles, mumps and rubella (MMR) and autism. Although his work was discredited and later retracted, the ideas he promoted had a significant impact on public health: MMR vaccination rates in the UK fell from $92 \%$ in 1995 to a low $79 \%$ in 2003 , well below the $95 \%$ rate required to achieve herd immunity, according to the WHO. Similar events occurred in the US, Ireland, Italy, and other countries that experienced severe measles outbreaks shortly thereafter. This was largely due to low vaccination coverage as a result of vaccination abandonment caused by completely inaccurate and discredited claims about its dangers (Kennedy, 2019; Poland \& Jacobson, 2011: 98). 
civil rights advocates. ${ }^{4}$ Indirectly, this has also strengthened opposition to public health measures, which are also seen as a form of restriction on liberties and civil rights. Many civil society groups engaged in this struggle also have a very clear political agenda, so that public health issues are often only a motive for their political action.

At the same time, the intensified processes of democratization and the increasingly developed awareness of civil rights from the end of the last century and the beginning of this century influence the growing questioning of the functioning of democratic institutions and political power. Political decision-making is increasingly taking place as a compromise and collusion between political elites, often under the influence of interest lobbies, and is less and less based on the expressed interests of citizens. Such decisions therefore lack sufficient legitimacy and are the cause of citizens' disenchantment with politicians, as well as cynicism and apathy (Stoker, 2006, 32-92). The negative effects of the global neoliberal economy, particularly increasing socio-economic inequalities, have further contributed to this (Schwartzman, 2004; Stiglitz, 2004, 2015). Liberal democracy is increasingly characterized by a crisis of legitimacy, representativeness and functioning of the political system, i.e. the state of post-democracy. ${ }^{5}$

${ }^{4}$ Immediately after the terrorist attack of September 11, the US Congress passed the USA Patriot Act, a law authorizing security agencies to conduct wiretaps, conduct searches, monitor the Internet, control financial transactions, and share grand jury testimony (War on Terror campaign). Despite criticism from numerous civil society associations, the Congress has subordinated civil liberty to security with this law. Moreover, at the behest of the US, as well as UN, many other countries have enacted anti-terror laws that restrict civil liberties and expand law enforcement powers in the name of protecting national security. In many countries, authoritarian political authorities have used this to silence opposition, especially liberal and pro-democracy opposition (Whitaker, 2007). Subsequently, the WHO has adopted a militarized security model for public health, describing pandemics (not only dangerous and rare diseases such as Ebola, SARS, or the already eradicated smallpox, but also influenza) as the highest security threat, on par with bioterrorism, environmental and nuclear attacks (WHO, 2007). Security and safety have thus become central categories of public health.

5 Post-democracy is most evident in the consequences of applying the principle of economic (market) rationality to political discourse on issues of political community, to political decision-making, and to the actions of the state. As a result, democracy in the classical sense (as the rule of the people) is transformed into a formal, representative political order that primarily protects the rights and interests of the individual and relegates the collective (general) interest and political thinking of the community to the background. The consequences of the implementation of neoliberal principles are manifold. On the one hand, they are manifested in a decrease in the political participation of citizens and the ability of society to articulate the public interest and make collective decisions in accordance with the common good and moral norms, and in a shift of political power from legitimate democratic factors to external factors. On the other hand, they are reflected in significant restrictions on the functions of the welfare state, which act as mechanisms to compensate for socio-economic differences. The result is a reduction of citizens' socio-economic rights that significantly violates socio-economic security, increases inequality and ultimately leads to political inequality, both globally and at the level of nation states. The general decline of trust in political power and political action and the discontent of large social groups in many societies are increasing, calling into question the legitimacy of the democratic order in general (Crouch, 2004: 1-52, 78-103; Ranciere, 2008: 24-26, 65-67). 
Contributing to all this are the processes of social restructuring driven by the new technological paradigm, especially the changes brought about by information and communication technologies. There is a dissolution of the class structure of industrial society, and with it a transformation of collective (class, ideological, political, value) identities into multi-identities. The trust and identification of citizens with the classical mainstream parties is diminishing, which is a direct consequence of this process, but also due to their decreasing capacity to respond to these challenges. Austerity policies after 2008, instead of overcoming the crisis faster, have increased social inequalities in many countries (Hayes, 2017; OXFAM, 2013). The inability of governments to deal with the challenges of terrorism and the recent migrant crisis has deepened divisions within democratic societies and increased citizens' distrust of the authorities, but also of other social groups. Under these conditions, the discontent of many socio-economically disadvantaged social groups and those with a sense of alienation and social exclusion became a fertile ground for the strengthening of various mostly illiberal populist options.

\section{Populist instrumentalization of the anti-vaccination opponents}

Although anti-vaccinationists have not succeeded in suppressing vaccination as the most prominent public health measure, ${ }^{6}$ their protests are less and less a struggle against the restriction of civil rights and liberties by public health measures, but increasingly an instrument to achieve very specific political goals. While anti-vaccination movements from the late $19^{\text {th }}$ to the late $20^{\text {th }}$ century were predominantly lower and working class, today's anti-vaccine movements and groups are much more diverse in structure - ranging from committed populists with political agendas and conspiracy theorists to upper middle class, relatively educated and informed, with complex rationales for their beliefs related to a mixture of worldviews about the environment, healing, holism and critical reading of scientific and alternative literature (Wolfe \& Sharp, 2002). Today, these are diverse social groups, from the uneducated who are unable to understand the facts and health risks - and therefore do not accept

6 Of the 28 countries in the European Union, in addition to Iceland and Norway, 15 countries require at least one vaccination, mainly in Central and Eastern European countries, and 15 countries only make recommendations. Penalties for refusing vaccination without a medically justified reason vary from country to country, ranging from criminal charges and fines to inability to enroll in preschools and schools. Vaccination coverage is about $90 \%$ in most countries, whether or not vaccination is mandated. In the US, law does not require vaccination, but it is a prerequisite for enrollment in public and private schools, and vaccination coverage varies among states. Medical and religious reasons are respected by 48 states, philosophical reasons by 19 , and only two states respect no reasons other than medical. The vaccination coverage rate for the recommended vaccines is about $90 \%$ in the US. It is similar in Canada and Australia, while in South American countries vaccination is generally compulsory. In Israel, vaccination is not mandatory but is part of a basket of health insurance benefits (Majer, Jureša \& Musil, 2017, 2017; NCSL 2021). 
scientific arguments and public health measures - to those radical, marginal but very vocal actors who use deliberate falsehoods, intimidation, falsified data and threats of violence to prevent public health measures such as vaccination, which are regularly an integral part of the political agenda of populist radical or illiberal parties, movements and groups (Poland \& Jacobson, 2011: 98).

In their political agendas promoting anti-elite fight, conspiracy theories, and radicalism, anti-vaccine ideas fit perfectly. The pandemic situation, on the other hand, is a very favorable environment for their activities and a wider reception of their views. Populism - regardless of ideological characteristics that go from left to right ${ }^{7}-$ opposes the people, as a single and moral entity, and elites, who are considered corrupt and morally inferior and who, along with dangerous others, deprive (or try to deprive) the sovereign people of their political and economic rights and values (Albertazzi \& McDonnell, 2008: 3; Mudde, 2004; Mudde \& Kaltwasser, 2017).

Populists, calling upon the people and the interests of the ordinary man, capitalize on citizen discontent and blame the government, elites, minorities, immigrants (dangerous others) for the situation. ${ }^{8}$ By advocating a direct relationship with the people, they regularly feed distrust in state institutions and political power and offer simple solutions to complex social and political problems (Šalaj, 2012; Urbinati, 1998). By fostering conflict between the people and the elite, populists display strong antiintellectualism and question experts, intellectuals, and scientific institutions, which they see as protagonists of elite interests. The rejection of scientific knowledge and facts is therefore an integral part of their political action, and such attitudes acquire the characteristics of a political opposition (Merkley, 2020). Part of such populist mobilization is the controversy over the implementation of epidemiological measures and vaccination, which has been particularly evident in the current COVID-19 crisis. Populist actors, especially radical ones, in almost all democratic societies exploit the public fear created by the COVID-19 pandemic by opposing public health measures and spreading doubts about the effectiveness of vaccination to achieve their political goals (Jäger \& Borriello, 2020; Speed \& Mannion, 2017, 2020). Populist movements,

7 Populism is not primarily an ideology, but a political discourse, style, and rhetoric used by various political actors. Populism is present across the political spectrum, from far left to far right, and functions primarily as a mean or form of a particular ideology. (Meijers \& Zaslove, 2021). In Europe, populist parties usually come from the right (e.g. Front National, AfD, UKIP), but can also be left-wing (e.g. SYRIZA, Podemos) or without ideological self-determination (e.g. 5SM).

8 The definition of the people depends on the ideological determination: for right-wing populists it is an ethnic group or nation, for left-wing populists a class. The meaning of elites also varies. It can refer to political, economic, cultural, media and legal elites, but also to credible experts. In general, left-wing populists' hostility toward elites is currently based on concerns about economic inequality, wealth, and privilege among business elites, while right-wing populists manifest hostility toward excessive government power and size or minority groups (ethnic, racial, immigrant) as dangerous others (Albertazzi \& McDonnell, 2008; Merkley, 2020). 
as well as populist politicians and/or governments, thus systematically spread distrust of experts, science and facts.

The effects of such action are destructive in many ways. In the political sphere, populists' advocacy of extra-institutional action and a direct relationship with the people undermines the procedural and representative dimensions of the functioning of a democratic system. In the field of public health, this in turn means the rejection of medical knowledge and its replacement by myths and prejudices. Moreover, in the medical dimension, the populist slogans of defending "ordinary people" from the "corrupt elite" imply a "medical conspiracy," that is, an interlocking of interests and corruption between doctors and pharmaceutical companies. Although this is claimed regularly without evidence and based only on a few sporadic cases, it certainly arouses suspicion and undermines trust. Indeed, vaccination is about everyone's health, so acceptance of the vaccine depends directly on trust in the medical profession and institutions, but also on knowledge, i.e. knowing and understanding the facts. Stirring up mistrust and distorting the facts and spreading lies leads to insecurity and mistrust, and discontent is directed against the government and the state, against political rivals and "dangerous others".

\section{Populism and the COVID-19 crisis}

In the context of the COVID-19 pandemic, this had fatal consequences for people's health and lives. Contributing factors were, firstly, denial of the danger, deception of the public and a series of misinformation repeatedly presented by some populist politicians. ${ }^{9}$ This subsequently increased distrust of experts and other politicians who advocated the introduction of and compliance with epidemiological measures. Secondly, the incompetence of many governments and national headquarters in dealing with the COVID-19 crisis contributed, particularly the inconsistency in implementing epidemiological measures and informing the public. Decisions on public health measures to combat the epidemic are not transparent in many countries, even in established democracies, and are not always based on scientific premises (HRW, 2020; Mesquita, Kapilashrami \& Meier, 2021: 22, 26). Moreover, they are often guided by economic and political goals (favoring certain social groups, entrepreneurs, the church, or self-interest in securing a position of power). This undermines the already eroded trust in political authorities and reduces the credibility of the expert staffs that led the epidemiological measures. After scientists had developed vaccines in an extremely short time, problematic arrangements for their procurement and distribution as well as inefficient organization of vaccination further undermined trust in political authorities and the responsible institutions.

9 Among several, D. Trump, J. Bolsonaro, B. Grillo and M. Le Pen stand out, while e.g. B. Johnson or V. Zelensky, initially strong deniers of the danger, later backed down under the pressure of the facts (high infection rates in the UK and Ukraine) and their own disease of COVID-19. 
Finally, the state of the infodemic - excessive amounts of disparate and often unverified, inaccurate and/or contradictory information, primarily mediated by digital communications and social networks that allowed their extremely rapid and widespread dissemination - has affected the suppression of credible information and the disorientation of many citizens regarding preventive measures to be taken, hindering an effective public health response. In addition, the infodemic has spread mistrust, fear, and speculation, as well as the production of health-threatening misinformation and medical advice. ${ }^{10}$

The influence of populist actors on public opinion and on the perception of public health measures has been shown to be significant. For example, there is a significant positive correlation between the percentage of people in the country who voted for populist parties and the percentage who believe that vaccines are not important and not effective (Kennedy, 2019,3). That is, the higher the percentage of voters for populist parties in a country, the higher the percentage of the population that believes vaccines are not effective. Distrust of vaccines and political populism are driven by similar dynamics: deep distrust of elites and experts (Devine et al., 2021; Kennedy, 2019). Hence the tendency to adopt conspiracy theories to explain the COVID-19 epidemic among supporters of populist actors and their rejection of the recommendations of public health authorities. ${ }^{11}$ Populism thus emerges as a strong predictor of belief in conspiracy theories, as does the consumption of conservative media content (Stecula \& Pickup, 2021). The rise of populist anti-establishment parties threatens further negative effects, since such parties support, legitimize, and - if elected - legalize opposition to vaccination. For example, left-wing populist governments (such as those in Greece and Italy), which traditionally advocate for strong state intervention in almost all policy arenas, have called for the abolition of compulsory vaccination programs, which is also strongly supported by the far-right Front National in France,

10 Although digital media expanded the communicative and political sphere of influence of citizens, they simultaneously became a means of populist mobilization and political manipulation. Populists are regularly aligned with the anti-vaccine movement in spreading half-truths or fake news, especially through social media, to create and sustain moral panic and fear, which in turn is fertile ground for their actions (Speed \& Mannion 2017). The inability to separate true information from misinformation characterizes a post-truth world in which the influence of fake news and misinformation on shaping public opinion is often greater than the influence of objective facts. Under these conditions, vaccination programs face new challenges, particularly in the area of communication, to avoid public concern, explain facts, and eliminate uncertainty as the main reason for opposition to vaccination (Ali \& Celentano, 2017).

11 There are numerous conspiracy theories related to the COVID-19 pandemic, from those that the virus was produced in China as a bioweapon and deliberately released among the population, those that the pandemic was initiated by pharmaceutical companies for profit through the sale of vaccines, to those that the pandemic was deliberately induced to destroy economies or allow governments to achieve their anti-democratic goals, then about the link between $5 \mathrm{G}$ technology and the spread of the pandemic, about the vaccine as a means to microchip people for government control, about the harmfulness of vaccines to human health or even the spread of contagion through vaccines, etc. (Stein et al., 2021). 
which is a very vocal opposition to the current government. This willingness to accept the demands of the vaccination skeptics should be understood in terms of their populist, anti-elitist and anti-establishment character, rather than in terms of any particular ideology (Kennedy \& Michailidou, 2017).

The political and socio-economic marginalization of larger social groups, their discontent and sense of existential and political vulnerability are the main preconditions for the acceptance and spread of such attitudes. It is expected that the negative socioeconomic consequences after the exit from the pandemic will have an impact on the reinforcement of anti-immigrant, xenophobic, nationalist and racist attitudes (Speed \& Mannion, 2020).

\section{Concluding remarks}

The COVID-19 pandemic - unprecedented in modern history in terms of its scale and health and socio-economic consequences - has brought with it, besides an economic crisis, also a political crisis. In democratic societies, it has manifested itself in particular through an accentuated tension between individual freedom and collective safety, between civil rights and the right to life and health as fundamental human rights. The pandemic has highlighted the competitive relationship between the two rights and brought to the fore the question of their harmonization.

Crisis management therefore involves not only the selection and implementation of appropriate public health measures but also the management of conflicts between individual and collective interests. The content, scope, duration and implementation of health policy measures, as well as their acceptance from the point of view of protecting liberties and civil rights, have become a challenge not only for political authorities but also for entire societies, calling into question their democratic functionality and stability.

Public health measures aimed at preserving the health and well-being of the community had, since their inception, taken precedence over individual rights and liberties, since the economic power of society and the political power of the state depended largely on the size and health of the population, and public health measures contributed directly to this. The state therefore undertook to protect the life and health of its citizens as a common good and public interest. It is on this basis that the state establishes its right to restrict the freedoms and rights of individuals in order to protect the common good when these would make up a danger to the life, health and safety of others. In this way, the state has the function of protecting the right to life and health as fundamental human rights, which indirectly protects civil rights that derive from the legal and political acquis of democratic societies. 
On this basis, health authorities over time have significantly improved public welfare and the quality of health and life for the broadest groups in society. The success of these programs - which necessarily involved certain restrictions on civil liberties - allowed for social changes that fostered the strengthening of civil rights and liberties and greater democratization in general. In this socio-political context, the classic conflict between individual liberties and a benevolent state, that is, between the rights of the individual and the rights of the community, has taken on different forms compared to earlier periods, and the right of the state is under serious pressure to be reconsidered.

The crisis of modern liberal democracy and the rise of populist illiberal political actors has given this conflict a quite new dimension. It is most evident in the instrumentalization of civil rights as a means in the struggle for one's own political goals, often aimed at restricting these rights precisely. In a pandemic situation, this instrumentalization is most evident in the opposition to epidemiological measures and vaccinations, which are presented as an attack by the state on citizens' freedom and rights. From a public health standpoint, such action has detrimental public health implications due to the obstruction of public health measures. From a political point of view, this has deepened distrust of the government and institutions, which has reduced their effectiveness in implementing the measures. In addition, some governments have exploited the situation to strengthen their political position and suppress criticism, which regularly indicates democratic backsliding (cf. FRA, 2021; Repucci \& Slipowitz, 2020).

It turns out, however, that the tension between human rights and civil rights, that is, between safety and liberty, community rights and individual rights, does not mean that one excludes the other. On the contrary, these two rights are complementary and the exercise of one strengthens the other. Indeed, the historical development of this relationship shows that the protection of the collective interest - whenever it was in line with the democratic process and directed towards the common good - ultimately created the conditions for greater freedom and better protection of citizens' rights. This should be a lesson for the current crisis, which has led to serious tensions between these two rights.

Thus, when implementing public health measures that involve restrictions, it is crucial that citizens accept them voluntarily because they are informed and understand the public interest. This in turn is an important task for the state to avoid the feeling that the measures have been imposed. In doing so, the state should provide timely, scientifically sound and rational information, the justification of the measures in laws and the scope and content of the measures should be appropriate to the situation and the degree of risk. This is the only way to gain the necessary trust of citizens, and not through political opportunism. In the same way, the populist instrumentalization of citizens' rights for illiberal purposes can be downplayed. In the absence of such an approach, and under conditions of spreading misinformation and politicizing 
epidemiological measures, divisions and hostility persist instead of generating a sense of unity and the need for a common solution to the crisis. Individual freedom and personal responsibility are most meaningful when actors have sufficient information about themselves and their environment and are aware of the social costs of irresponsible use of the rights and liberties offered by a democratic order.

\section{References}

1. Ackerknect, C. (1948). Anticontagionism between 1821-1867. Bull History Med, 22: 562-593.

2. Ali, K. A. and Celentano, L. P. (2017). Addressing vaccine hesitancy in the "post-truth" era. Eurohealth, (23) 4: 16-20.

3. Baldwin, P. (1999). Contagion and the State in Europe 1820-1930. Cambridge, UK: Cambridge University Press.

4. Albertazzi, D. and McDonnell, D. (2008). Introduction: The Sceptre and the Spectre, in: Albertazzi, D. and McDonnell, D. (Eds.). Twenty-First Century Populism: The Spectre of Western European Democracy (pp. 1-11). New York: Palgrave.

5. Bayer, R. (1989). Private Acts Social Consequences: AIDS and the Politics of Public Health. New York, NY, USA: Free Press.

6. Borovečki, A. and Lang, S. (2001). Zdravstvene i socijalne institucije staroga Dubrovnika. Revija za socijalnu politiku, 8 (3-4): 301-308.

7. Colgrove, J. and Bayer, R. (2005). Manifold restraints: liberty, public health, and the legacy of Jacobson v. Massachusetts. American journal of public health, (95) 4: 571-576.

8. Crouch, C. (2004). Post-Democracy. Cambridge: Polity Press.

9. Declaration of the Right of Man and the Citizen, 26 August 1789. https://www. refworld.org/docid/3ae6b52410.html.

10. Devine, D.; Gaskell, J.; Jennings, W.; Stoker, G. (2021). Trust and the Coronavirus Pandemic: What are the Consequences of and for Trust? An Early Review of the Literature. Political Studies Review, (19) 2: 274-285.

11. European Convention for the Protection of Human Rights and Fundamental Freedoms, as amended by Protocols Nos. 11 and 14, 4 November 1950, ETS 5. https://www.refworld.org/docid/3ae6b3b04.html.

12. FRA (2021). Fundamental Rights Report 2021. European Union Agency for Fundamental Rights.

13. Gostin, L. O. et al. (2017). Advancing the Right to Health - The Vital Role of Law. American Journal of Public Health, 107 (11): 1755-1756.

14. Hayes, G. (2017). Regimes of Austerity, in: Flesher F. C. and Hayes, G. (Eds.). Resisting Austerity: Collective Action in Europe in the Wake of the Global Financial Crisis. Abingdon: Routledge, 21-35. 
15. HRW (2020). Human Rights Dimensions of the COVID-19 Response (March 19). https://www.hrw.org/news/2020/03/19/human-rights-dimensions-covid-19-response.

16. Jäger, A. and Borriello, A. (2020). Making Sense of Populism. Catalyst, (3) 4.

17. Kennedy, J. (2019). Populist politics and vaccine hesitancy in Western Europe: An analysis of national-level data. European Journal of Public Health, 29 (3): 512-516.

18. Kennedy, J. and Michailidou, D. (2017). Divergent policy responses to increasing vaccine hesitancy in southern Europe. Lancet Infectious Diseases, 17 (9): 900.

19. Larson, H. J. et al. (2016). The State of Vaccine Confidence 2016: Global Insights Through a 67-Country Survey. EBioMedicine, 12: 295-301.

20. Majer, M., Jureša, V. i Musil, V. (2017). Politike cijepljenja u svijetu - Knjiga sažetaka V. hrvatski kongres školske i sveučilišne medicine Djeca i mladi - izazov za budućnost, 14-15. Zagreb: HDŠZM/HLZ.

21. Meijers M. J. and Zaslove, A. (2021). Measuring populism in political parties: Appraisal of a new approach. Comparative Political Studies, 54 (2): 372-407.

22. Merkley, E. (2020). Anti-Intellectualism, Populism, and Motivated Resistance to Expert Consensus. Public Opinion Quarterly, 84 (1): 24-48.

23. Mesquita, J. B.; Kapilashrami, A. and Meier, B. M. (2021). Human Rights Dimensions of the COVID-19 Pandemic, Background paper 11, The Independent Panel for Pandemic Preparedness and Response.

24. Mudde, C. (2004). The Populist Zeitgeist. Government and Opposition, (39) 4: 541-563.

25. Mudde, C. and Kaltwasser C. R. (2017). Populism: A Very Short Introduction. New York: Oxford University Press.

26. NCSL, (2021). National Conference of State Legislatures. https://www.ncsl.org/ research/health/school-immunization-exemption-state-laws.aspx.

27. OXFAM, (2013). A Cautionary Tale. The true cost of austerity and inequality in Europe. Oxford: Oxfam.

28. Poland G. A. and Jacobson, R. M. (2011). The age-old struggle against the antivaccinationists. The New England Journal of Medicine, 364 (2): 97-99.

29. Ranciere, J. (2008). Mržnja demokracije. Zagreb: Naklada Ljevak.

30. Repucci, S. and Slipowitz, A. (2020). Democracy under Lockdown. The Impact of COVID-19 on the Global Struggle for Freedom. Freedom House.

31. Stiglitz, J. E. (2015). Inequality and Economic Growth. The Political Quarterly, 86 (1): 134-155.

32. Stiglitz, J. (2004). Globalizacija i dvojbe koje izaziva. Zagreb: Algoritam.

33. Schwartzman, K. C. (2004). Globalization: The New Mechanism of Dependency, in: Reifer, T. E. (Ed.). Globalization, Hegemony and Power. Antisystemic Movements and the Global System. Boulder: Paradigm Publishers, 110-130.

34. Speed, E. and Mannion, R. (2020). Populism and health policy: three international case studies of right-wing populist policy frames. Sociology of Health \& Illness, 42 (8): 1967-1981. 
35. Speed E. and Mannion R. (2017). The rise of post-truth populism in pluralist liberal democracies: challenges for health policy. International Journal of Health Policy and Management, (6) 5: 249-251.

36. Stein, R. A.; Ometa, O.; Pachtman, S. S.; Katz, A.; Popitiu, M. I.; Brotherton, R. (2021). Conspiracy theories in the era of COVID-19: A tale of two pandemics. The International Journal of Clinical Practice, 75 (2).

37. Stecula D. A. and Pickup M. (2021). How populism and conservative media fuel conspiracy beliefs about COVID-19 and what it means for COVID-19 behaviors. Research \& Politics, January 2021.

38. Stoker, G. (2006). Why Politics Matters: Making Democracy Work. London: Palgrave Macmillan.

39. Šalaj, B. (2012). Suvremeni populizam. Anali Hrvatskog politološkog društva, 9 (1): 21-49.

40. Štampar, A. (1934). Deset godina unapredivanja narodnog zdravlja, Zagreb: Tisak Zaklade tiskare Narodnih novina.

41. UN General Assembly (1976). International Covenant on Civil and Political Rights, adopted 16 December 1966, entry into force 23 March 1976. United Nations, Treaty Series, Vol. 999, p. 171. https://www.refworld.org/docid/3ae6b3aa0.html.

42. UN General Assembly (1948). Universal Declaration of Human Rights, adopted 10 December 1948, 217 A (III). https://www.refworld.org/docid/3ae6b3712c. html.

43. Urbinati, N. (1998). Democracy and Populism. Constellations, (5) 1: 110-124.

44. U.S. Supreme Court (1905). Jacobson v. Massachusetts, 197 U.S. 11 (1905), No. 70, Argued December 6, 1904, Decided February 20, 1905.

45. WHO (2007). A Safer Future: Global Public Health Security in the 21st Century. Geneva, Switzerland: World Health Organization.

46. Whitaker, B. (2007). Exporting the Patriot Act? Democracy and the "War on Terror" in the Third World. Third World Quarterly, 28 (5): 1017-1032.

47. Winslow C. E. A. (1920). The Untilled Fields of Public Health. Science, 51 (1306): 23-33.

48. Wolfe, R. M. and Sharp, L. K. (2002). Anti-vaccinationists past and present. BMJ (Clinical research ed.), 325 (7361): 430-432. 
Izvorni znanstveni rad

\title{
Demokracija u doba pandemije: građanska i ljudska prava i izbor između slobode i sigurnosti
}

\author{
Pero Maldini
}

Sveučilište u Dubrovniku, Odjel za komunikologiju, Hrvatska

e-mail:pero.maldini@unidu.hr

\section{Sažetak}

Zdravstvena i ekonomska kriza nastala COVID-19 pandemijom prerasla je i u političku krizu. Ona se očituje prvenstveno u izazovima s kojima se suočavaju institucije liberalne demokracije, prije svega u osiguranju legitimnog pravno-političkog okvira djelovanja i upravljanja krizom u izvanrednoj situaciji. Ovaj članak istražuje primjenu javnozdravstvenih mjera (epidemiološke mjere, cijepljenje) usmjerenih zaštiti života i zdravlja, koje inherentno uključuju i ograničenja građanskih sloboda, te analizira njihovu legitimnost i primjerenost u odnosu na standarde liberalne demokracije. Teorijski i pravno-politički okvir analize jest odnos između slobode i sigurnosti, odnosno građanskih prava i sloboda koje jamči liberalna demokracija i prava na život i zaštitu zdravlja kao temeljnog ljudskog prava. Temeljem razgraničenja tih dvaju pojmova i analize opsega i načina implementacije javnozdravstvenih mjera - posebice u aktualnom kontekstu krize liberalne demokracije i populističke instrumentalizacije građanskih prava za partikularne političke ciljeve te stanja infodemije - utvrđuju se specifičnosti tog odnosa u aktualnoj pandemijskoj situaciji i procjenjuje se legitimnost poduzetih mjera. $\mathrm{Na}$ osnovi te analize, zaključuje se kako, usprkos konkurentskom odnosu i tenziji između individualne slobode i javne sigurnosti - osobito naglašenima u pandemijskoj situaciji - građanska i ljudska prava se međusobno ne isključuju. Naprotiv, ona se nadopunjuju i jedna su preduvjet drugima, pa se na tom tragu upućuje na mogućnosti postizanja ravnoteže među njima, posljedično i na mogućnosti prevladavanja pandemijske krize.

Ključne riječi: ljudska prava, građanska prava, epidemiološke mjere, cijepljenje, COVID-19 pandemija. 